\title{
İbn Meymun’a Göre Yahudilik’te İman Esasları*
}

\author{
YASIN MERAL \\ AR.GÖR., ANKARA ÜNIVERSITESİ İLAHIYAT FAKÜLTESI \\ yasinmera11979@gmail.com
}

\begin{abstract}
Özet
Yahudi tarihi boyunca birçok din bilgini iman esasları listesi hazırlamıştır. Ortaçağın büyük Yahudi düşünürü İbn Meymun da iman esasları listesi hazırlayarak kendi listesindeki esaslara uymanın her Yahudi için bir zorunluluk olduğunu ifade etmektedir. Bu makalede öncelikle Yahudi tarihinde belli başlı iman esasları listesi hazırlayan din bilginleri ve listeleri hakkında kısa bilgiler verilecektir. Makalenin temel kısmını ise bugün itibariyle listesi en fazla tutulan İbn Meymun'un Yahudi şeriatının usul ve kaidelerini ele aldığı on üç maddelik iman esasları oluşturmaktadır. Alana bir katkı olması amacıyla ve araştırmacıların dikkatine sunulmak üzere İbn Meymun'un iman esasları listesinin Judeo-Arabic orijinal metni ve Türkçe tercümesi ekte sunulacaktır.
\end{abstract}

Anahtar Kelimeler: Yahudilik, İman Esasları, İbn Meymun, Nesh, Tevrat, JudeoArabic

\begin{abstract}
Articles of Faith in Judaism according to Ibn Maimun

In the course of Jewish history, there apperaed a plenty of thinkers who prepared special lists for the articles of faith. Ibn Maimun, great Jewish thinker of Medieval Ages, also listed the articles of faith and stressed his list's binding status. In this article, it will firstly be presented the famous lists by Jewish thinkers. The bulk of the study consists of Ibn Maimun's articles of faith that is the most popular list of Jewish history. I translate thirteen articles of faith presenting with the Judeo-Arabic original text aiming to contribute to the field and to offer to the attention of the researchers.
\end{abstract}

Key Words: Judaism, Articles of Faith, Ibn Maimun, Naskh, Torah, Judeo-Arabic

* Bu makaleye yaptıkları katkılardan dolayı hocam Prof. Dr. Baki Adam ve Dr. Uri Melammed'e teşekkür ederim. 


\section{Giriş}

Yahudi tarihi boyunca bir çok iman esasları listesi kaleme alınmıştır. Yahudi din bilginleri listelerindeki esasları ifade etmek üzere esas, ilke, temel, kök ve rukün gibi anlamlara gelen ikkarim, şoraşim, yasodot, işurim ve amudim kavramlarını kullanmışlardır.

Yahudilik'te iman esasları listesi, bilindiği kadarıyla, ilk olarak Yahudi filozof Philo (ö. MS. 50) tarafından yapılmıştır. Hz. Musa'nın beş temel esas ortaya koyduğunu ifade eden Philo, bunları Tanrı'nın varlığı, birliği, kainatın tek ve yaratılmış oluşu ve kader (ilahî takdir) inancı olarak sıralamaktadır. ${ }^{1}$ Philo'dan sonra ortaçağa kadar iman esasları ile ilgili bir liste denemesi bilinmemektedir. Ortaçağda ilk olarak Rav Saadya Gaon (ö. 942) bu alanda bir deneme yapmıştır. ${ }^{2}$ Gaon, Kitabu'l-Emânât vel-İ'tikâdât adlı eserinin bölüm başlıklarını iman esasları listesi tarzında oluşturmuştur. Bu başlıklar; bütün mevcudatın yaratılmış olduğu, hepsinin bir yaratıcısının bulunduğu, emirnehiy, itaat-isyan, iyilik-kötülük, mükâfât-ceza, ve ölülerin diriltilmesi gibi konulardan oluşmaktadır. ${ }^{3}$ Saadya Gaon bunun yanında Allah'a imanın nasıl olması gerektiği hususunda da on maddelik bir liste hazırlamıştır. ${ }^{4}$ Onu takip eden asırlarda iman esasları listelerinde bir artış olduğu görülmektedir. Saadya Gaon sonrası ilk liste denemelerinden birisi Hananel ben Huşiel'e (ö. 1055) aittir. O, iman esaslarını Allah'a, peygamberlere, ahirete ve Mesih'in gelişine iman şeklinde listelemektedir. ${ }^{5}$ Ondan bir asır sonra Abraham ben Davud Halevi (ö. 1180) el-Akidetü' $r$-Râfia ${ }^{6}$ adlı eserinde altı temel esastan bahsetmektedir.

1 Philo, On the Creation of the Cosmos (De Opicifio Mundi), İngilizce'ye çeviren C.D. Yonge, 1890, s. 51; Philo of Alexandria, On the Creation of the Cosmos according to Moses, İngilizce'ye çeviren D.T. Runia, Brill 2001, ss. 92-93.

2 Konu ile ilgili bkz. Sami Baybal, "Saadia Gaon, Onun Ortaçağ Yahudi Felsefesini Oluşturma ve Yahudi Dogmasını Yeniden Formule Etme Çabaları", Selçuk Üniversitesi İlahiyat Fakültesi Dergisi, 15 (2003), ss. $169-189$.

3 Rav Saadya Gaon, Kitabu'l-Emânât vel-İ'tikâdât, ed. S. Landauer, Leiden, 1880.

4 Yosef Kafih, Peruşey Rabbenu Saadya Gaon al Ha-Tora, Mosad Rav Kook, Yeruşalayim 1963, ss. 175-6; Haggai ben Shammai, “Asarat İkkarey Emuna şel Rav Saadya Gaon”, Daat 37 (1996), ss. 11-26; Rav Saadya Gaon'a ait on maddelik bu esasların Judeo-Arabic (İbrani harfleriyle Arapça) orijinal metni ve Türkçe tercümesi tarafımızdan yayına hazırlanmaktadır.

5 Alexander Altmann, "Articles of Faith", Encyclopedia Judaica (Second Edition), ed. Fred Skolnik, Thomson Gale, 2007, II: 529.

6 Bu eser 1370 yılında Şlomo ben Lavi tarafindan Ha-Emuna Ha-Rama adiyla İbranice'ye, 1986 yılında da Norbert Samuelson tarafından "The Exalted Faith" adıyla İngilizce'ye çevrilmiştir. Ayrıca bu eser "Eran, Amira, 1990, Meqorotav ha-filosofiyyim shel Avraham ibn Daud be-sifro al- 'Aqîdah al-rafí "ah, $\mathrm{Ph} . \mathrm{D}$. thesis, Hebrew University Jerusalem" künyesiyle doktora tezi olarak çalışılmış ve eserin yeni edisyonu yapılmıştır. 
Bunlar Tanrı'nın varlığı, birliği, Tanrı'nın noksan sıfatlardan münezzeh oluşu, fiillerindeki kudret, peygamberlere iman ve kader (ilahî takdir) inancıdır. ${ }^{7}$

Abraham ben Davud Halevi'den sonraki dönemde İbn Meymun Yahudi tarihinin en meşhur iman esasları listesini hazırlamıştır. ${ }^{8}$ İbn Meymun'un listesi Yahudi dünyasında geniş kabul görmekle birlikte, ondan sonra da bu alanda çalışmalar devam etmiştir. Migdal David adlı eserin sahibi David ben Samuel Kohavî (13. yy) bunlardan biridir. Kohavî, listesini üç esas (ikkarim) ve yedi ilke (amudim) şeklinde oluşturmuştur. Üç esas; Tevrat'ın bütün emir ve kurallarını yerine getirmek, dinin akılla anlaşılmayacak esaslarına iman etmek ve Tevrat' 1 tam anlamak için felsefî ilimleri tahsil etmektir. Felsefî ilimleri tahsil maddesi, diğer listeler dikkate alındığında istisnaî bir esas olarak dikkat çekmektedir. Yedi ilke ise dünyanın yaratılmış oluşu, irade hürriyeti, kader (ilahî takdir) inancı, Tevrat'ın vahiy oluşu, mükâfât-ceza, kurtarıcı (Mesih) ve ölülerin diriltileceği inancından oluşmaktadır. ${ }^{9}$ Kohavî’nin çağdaşı olan Abba Mari Astruc, Minhat Kinaot adlı eserinde, bütün esasların özünü Tanrı (varl1ğ1, birliği, ezeli-ebedi oluşu) inancı, dünyanın yaratılmış oluşu ve kader (ilahî takdir) inancının oluşturduğunu belirtmektedir. ${ }^{10}$

İbn Meymun sonrası önemli Yahudi bilginlerinden birisi olan Hasday Crescas (ö. 1410) Or Adonay isimli eserinde iman esaslarını genelden özele üç grupta toplamaktadır. Tanrıyla ilgili birinci grupta Tanrı'nın varlığı, birliği ve cismanî olmayışı esaslarına yer veren Crescas, ikinci grupta Tanrı'nın herşeyi bilmesi, kader (ilahî takdir), Tanrı'nın kudreti, peygamberlik, irade hürriyeti ve Tevrat'in saadet rehberi oluşunu zikretmektedir. ${ }^{11}$ Üçüncü grupta ise Crescas, dünyanın yaratılmış oluşu, ruhun ölümsüzlüğü, mükâfât-ceza, ölülerin diriltilmesi, Tevrat'ın ebediliği, Hz. Musa'nın peygamberliğinin üstünlüğü, başkohe-

7 Abraham ben Davud, Ha-Emuna Ha-Rama, ed. Simson Weil, Frankfurt am Main 1852 (Yeni basim, Yeruşalayim 1967), 2:1-6, ss. 44-98.

8 İleride detaylı olarak işlenecek bu maddeler Tanrı'nın varlığı, birliğí, cismanî olmayışı, ezelî oluşu, ibadete layık oluşu, peygamberlik, Hz. Musa'nın peygamberliği, Tevrat'ın vahiy oluşu, Musa şeriatının neshedilmemiş oluşu, Tanrı'nın insanın fiillerini bilmesi, Tevrat'ın emirlerine uygun yaşayanların ödülle aykırı yaşayanların ceza ile karşılık göreceği, Mesih'in gelişi ve ölülerin diriltilmesi şeklindedir.

9 David ben Samuel Kohavî, Migdal David: Sefer Ha-Emuna, ed. Moshe Hirschler, Yeruşalayim 1983, ss. 10-11. Ayrıca Kohavî, metnin 10-11. sayfalarında liste halinde verdiği her bir esası 43-198 sayfaları arasında detaylıca işlemektedir.

10 Abba Mari Astruc, Minhat Kinaot, ed. M. J. Bisseliches, Pressburg 1838, Perek 4, s. 7.

11 Hasday Crescas, Or Adonay, ed. Shlomo Fisher, Sifrey Ramot, Yeruşalayim 1990, 2:1-6, ss. 123. Crescas sayfa 123 'te liste halinde verdiği esasları 123-272. sayfalar arasında detaylıca işlemektedir. 
nin Urim ve Tumim ${ }^{12}$ ile (manevî olarak) desteklendiği ve Mesih'in gelişi şeklinde sekiz esas sıralamaktadır. ${ }^{13}$ Crescas'ın ortaya koyduğu iman esaslarında diğerlerinden farklı olarak Urim ve Tumim maddesi dikkat çekmektedir.

Hasday Crescas'ın öğrencisi olan Yosef Albo (ö. 1444), Sefer Ha-İkkarim adlı eserinde Yahudiliğin esaslarını üç esasta özetlemektedir. Tanrı'nın varlığı, Tevrat'ın vahiy oluşu ve mükâfât-ceza inancı olarak zikredilen bu esaslar daha sonra her biri kendi içinde detaylandırılarak on bire çıkarılmaktadır. Buna göre Tanrı'nın varlığı esasına Tanrı'nın birliği, cismanî olmayışı, kıdem sahibi oluşu ve noksan sıfatlardan münezzeh oluşu eklenmiştir. Tevrat'ın vahiy oluşu esasına ise peygamberlik, Hz. Musa'nın peygamberliği ve Tanrı'nın mevcudatı bilmesi maddeleri ilave edilmiştir. Mükâfât ve cezanın hak oluşu esasına da Tanrı'nın kulları üzerinde ilahî bir takdirinin olduğu inancı eklenmiştir. Böylece üç temel esas üzerinden on bir iman esası açıklanmıştır. ${ }^{14}$

Onbeşinci yüzyıl Yahudi bilginlerinden Şim'on ben Tsemah Duran (ö. 1444), Ohev Mişpat adlı eserinde, İbn Meymun'un on üç maddelik listesindeki esasları özetlemiştir. O, İbn Meymun'un listesindeki ilk beş esası Tanrı'ya iman, altıdan dokuza kadar olan esasları Tevrat ve ondan on üçe kadar olan esasları da mükâfât-ceza inancı şeklinde ana başlıklarda toplamıştır. ${ }^{15}$ Isaac Arama (ö. 1494) ise Akedat Yitshak adlı eserinde dinin esaslarını Yahudi bayramları ile irtibatlandırmıştır. Ona göre Şabat dünyanın yaratılmış olduğunu, Pesah Tanrı'nın herşeye gücünün yettiğini, Şavuot peygamberlik ve Tevrat'ın vahiy olduğunu, Roş Ha-Şana kader inancını, Yom Kipur tevbe inancını ve Sukkot da mükâfât-ceza inancını temsil etmektedir. ${ }^{16}$

Yukarıda zikredilenlerin dışında başka Yahudi din bilginlerinin de liste denemesi yaptığ görülmektedir. Bunlardan biri olan Eliyahu Delmedigo, Behinat Ha-Dat (1496) adlı eserinde, iman esasları olarak İbn Meymun'un listesindeki maddeleri tekrar etmektedir. ${ }^{17}$ Yosef Yaavets (16. yy) ise Yasod Ha-Emuna ve

12 Mabet zamanında başkohen'in göğüslüğünde bulunan ve kura çekmek ve Tanrı'nın isteğini öğrenmek için kullanılan iki küçük nesne.

13 Crescas, Or Adonay, 3:1-8, s. 272.

14 Yosef Albo, Sefer Ha-Ikkarim, ed. Isaac Husik, Jewish Publication Society, 1946, I.15, ss. 129-137.

15 Şim'on ben Tsemah Duran, Ohev Mişpat, Venetsia 1589, Perek 8, ss. 13b-14a; İbn Meymun’un esaslarının gruplandırılması için bkz. Menachem Kellner, Dogma in Medieval Jewish Thought, Oxford University Press, 1986, ss. 24-34.

16 Yitshak Arama, Akedat Yitshak, ed. Hayyim Yosef Pollak, Lvov 1868, Şaar 67, ss. 106b-107a.

17 Eliyahu Delmedigo, Behinat Ha-Dat, ed. Isaac Samuel Reggio, Wien 1833, ss. 21-28. 
Maamar Ha-Ahdut adlı risalelerinde Yahudiliğin esaslarını dünyanın yaratılmış oluşu, kader (ilahî takdir) ve Tanrı'nın birliği şeklinde sıralamaktadır. ${ }^{18}$

Rabbani Yahudiler arasında olduğu gibi Karailer arasında da iman esasları listelesi oluşturanlar vardır. On ikinci yüzyıl Karaî bilginlerinden Yahuda Hadasi, Eşkol Ha-Kofer adlı eserinde iman esaslarını on madde halinde s1ralamaktadır. Tanrı'nın birliği, ebediliği, dünyanın yaratıcısı oluşu, ölülerin diriltilmesi, mabedin kutsallığı, mükâfât-ceza inancı gibi temel konuları içeren bu listenin en dikkat çekici maddesi altıncı maddedir. Bu maddeye göre Tevrat' 1 tam anlamak için İbranice'yi iyi bir şekilde öğrenmek gereklidir. ${ }^{19} \mathrm{Bu}$ liste daha sonra Eliyahu Başyatçı tarafindan 1480 yılında tamamlanan Adderet Eliyahu'da son halini almıştır. ${ }^{20}$

İnanç esaslarını listeleyen bir başka Karai bilgin on dördüncü yüzyılda yaşamış İsrail bin Samuel Mağribî'dir. Mağribî'nin altı maddeden oluşan listesinde Tanrının varlığı, Hz. Musa'nın peygamberliği, peygamberlere iman, Tevrat'in vahiy oluşu, mabedin özel konumu ve mükafât-ceza konuları yer almaktadır. Arapça kaleme alınan bu listede Mağribi, mabedin kutsallığını ifade etmek üzere İslâmî bir kavram olan kıble kelimesini kullanmaktadır. Mağribî, Tanrı'nın nazarının sürekli Kudüs'teki mabet üzerinde olduğunu ve dua, sünnet ve hayvan kesimi sırasında yüzlerin mabede doğru çevrilmesi gerektiğini ifade etmektedir. ${ }^{21}$

Yahudi tarihindeki bu liste denemelerinden farklı olarak Isaac Abravanel (ö. 1508) Roş Amana isimli eserinde Yahudiliğin esasları şeklinde bir isimlendirmeyi reddetmektedir. İbn Meymun'un listesi başta olmak üzere kendisinden önceki iman esasları listelerini eleştiren Abravanel'e göre bir esas sayılması zorunluysa o da dünyanın yaratılmış oluşu olmalıdır. ${ }^{22}$

\section{İbn Meymun'un Listesi}

Ortaçağ Yahudi bilginlerinin en büyüğü sayılan İbn Meymun'un (ö.1204) on üç maddeden oluşan iman esasları listesi Yahudi geleneğindeki en meş-

18 Yosef Yaavets, Yasod Ha-Emuna, Warsaw 1871, ss. 2-3; Maamar Ha-Ahdut, Warsaw 1871, ss. 2-11.

19 Yahuda Hadasi, Eşkol Ha-Kofer, Gözleve 1836, ss. 21c-d.

20 Nathan Schur, "Creed”, Karaite Encyclopedia, Peter Lang Pub. Inc., 1995, s. 74.

21 Ernest Mainz, "The Credo of a Fourteenth Century Karaite", Proceedings of the American Academy for Jewish Research 22 (1953), s. 62; Abraham Shlomo Halkin, "A Karaite Creed”, Studies in Judaica, Karaitica and Islamica, Ed. Sheldon R. Brunswick, Bar Ilan University Press, Israel 1982, s. 152.

22 Yitshak Abravanel, Roş Amana, Warsaw 1881, Perek 22, s. 51. 
hur listedir. Kellner, ortaçağ Yahudi dogmasını analiz ettiği eserinde İbn Meymun'u Yahudi tarihinde sistematik ve bilinçli olarak iman esasları listesi hazırlayan ilk düşünür olarak zikretmektedir. ${ }^{23}$ Bugünkü Yahudi düşüncesinin oluşmasında çok büyük pay sahibi olan İbn Meymun, iman esasları listesini Şerhu'l-Mişna ${ }^{24}$ adlı eserinde vermektedir. ${ }^{25}$ Judeo-Arabic $^{26}$ olarak kaleme alınan bu esaslar Tanrı'nın varlığı, birliğii, cismanî olmayışı, ezelî oluşu, ibadete layık oluşu, peygamberlik, Hz. Musa'nın peygamberliği, Tevrat'ın vahiy oluşu, Hz. Musa'nın şeriatının neshedilmemiş oluşu, Tanrı'nın insanın fiillerini bilmesi, Tevrat'ın emirlerine uyanların mükâfâtla, uymayanların ceza ile karşıllk göreceği, Mesih'in gelişi ve ölülerin diriltilmesi şeklindedir. İman esaslarını Arapça kaleme alan İbn Meymun, bu esasları ifade etmek üzere kaide ve usul kavramlarını kullanmaktadır. Bunun yanında İbn Meymun'un esasları açıklarken İslâmî kavramları sıklıkla kullandığı görülmektedir.

İbn Meymun'un listesindeki maddeler üç ana konuyla ilişkilidir. İlk beş madde yaratıcı, altıdan dokuza kadar olan maddeler vahiy ve peygamberlik, ondan on üçe kadar olan maddeler de mükâfât-ceza ve kader (ilahî takdir) konularından oluşmaktadır. Bundan hareketle, her ne kadar iman esasları listesine açık bir atıf olmasa da bazı araştırmacılar İbn Meymun'un Delâletü'l-Hâirîn adlı eserini on üç maddelik iman esaslarının üç ana grupta mütalaa edilmiş hali olarak görmektedir. Zira Delâletü'l-Hâirîn bizzat İbn Meymun tarafından üç bölüm halinde kaleme alınmıştır. ${ }^{27} \mathrm{Bu}$ üç bölümden ilki Tanryyla ilgilidir. İkinci bölümde İbn Meymun, peygamberlik, vahiy ve Hz. Musa'nın peygamberliğini işlemektedir. Üçüncü bölümde ise mükâfâtceza, Tanrı'nın yaratılmışların fiillerini bilmesi ve kader gibi konuları ele almaktadır. Buna göre İbn Meymun, Mişna şerhinde halk için listelediği

23 Kellner, Dogma in Medieval Jewish Thought, s. 200.

$24 \mathrm{Bu}$ eser Kitabu's-Sirac olarak da tanınmıştır. Oysaki İbn Meymun, bu eser için bu ismi kullanmamaktadır. Müellif, kitaptan bahsederken Şerhu'l-Mişna tabirini kullanmaktadır. Kitabu 's-Sirac tabiri ise Halep Yahudileri tarafından bu esere verilmiş bir isimdir. Bu bilgiyi dikkatime sunan Dr. Uri Melammed'e teşekkür ederim.

25 İbn Meymun, Mishnah im Perush Rabbenu Moshe ben Maimon (Şerhu'l-Mişna), ed. Yosef Kafih, Mosad Ha-Rav Kook, Yeruşalayim 1963-1968, Sanhedrin 10.1, IV: 210-216.

26 Arapça metinlerin İbrani harfleri kullanılarak yazılmasıdır. Ortaçağda Arap-İslâm hâkimiyetinde yaşayan Yahudiler, bu yazı sitilini geliştirmişlerdir. Tanah'tan ayetler ve Yahudiliğe ait terimler orijinal İbranice olarak kullanılmıştır. Bu yazı sitili modern dönemde de hem Irak'ta hem de Kuzey Afrika'da kullanılmış olup Judeo-Arabic dilinde gazeteler ve değişik türde yayınlar yapılmıştır.

$27 \mathrm{Bu}$ eserin tahkiki Prof. Dr. Hüseyin Atay tarafından yapılmış ve Arap harfleriyle basılmıştır. Bkz. Musa bin Meymun, Delâletü'l-Hâirîn, tahk. Hüseyin Atay, Ankara Üniv. İlahiyat Fak. Yy, Ankara 1974. 
esasları, ilmî çevreler için kaleme aldığı Delâletü'l-Hâirîn'de felsefî tarzda üç ana başlıkta sunmaktadır. ${ }^{28}$

İbn Meymun, listesine aldığ 1 esaslara iman etmenin İsrail topluluğuna dâhil olmak için şart olduğunu ifade etmektedir. Ona göre bu esaslardan birine inanmayan Yahudi, İsrail topluluğundan çıkar ve dinin esasını inkar etmiş (kofer be-ikkar) olur. Bu tür kimseler min (sapkın), apikoros ${ }^{29}$ ve kotsets be-netiot $^{30}$ olarak isimlendirilir. ${ }^{31}$

İbn Meymun, listesinin bağlayıcı olduğunu ifade etse de onun listesi sonraki asırlarda Hasday Crescas, Yosef Albo ve Abravanel gibi din bilginleri tarafından eleştirilmiştir. ${ }^{32}$ Marc Shapiro, İbn Meymun'un iman esaslarını incelediği makalesinde bu esasların Yahudi teolojisinde son söz olarak kabul edilmediğini ifade etmektedir. ${ }^{33}$

İbn Meymun'a atfedilen ve Ani Maamin be-Emuna Şlema (tam bir inançla inanırım ki) şeklinde meşhur olan “amentü” bu şekliyle İbn Meymun'a ait olmayıp onun listesinin daha sonraki asırlarda şiir şeklinde formüle edilmiş halidir. ${ }^{34}$

28 Kellner, Dogma in Medieval Jewish Thought, ss. 49-53.

29 Her ne kadar Yunan düşünür Epikür'ü çağrıştırsa da Rabbani gelenek bu durumu göz ardı ederek kelimeyi

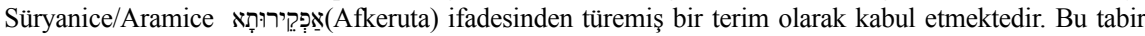
Rabbani literatürde yaygın olarak Tevrat'ın öğretilerini ve Tevrat bilginlerini küçümseyen ve tahkir eden insanlar için kullanılmaktadır. İbn Meymun da bu kelimenin Süryanice olduğunu ve şeriatın emirlerini veya din bilginlerini hafife alma ve aşağılama anlamına geldiğini ifade etmektedir. Rabbani gelenekteki bu genel anlamlandırmadan farklı olarak Yosef Albo (ö. 1444) bu kelimeyi Yunan filozof Epikür'le ve onun takipçileriyle ilişkilendirmektedir. (Yosef Albo, Sefer Ha-Ikkkarim, ed. Isaac Husik, Jewish Publication Society, 1946, I.10, ss. 98-99). Bu kelimeyi Yahudi geleneğinde zındıklığı ifade eden sembol bir isim olarak görmek mümkündür. Bkz. TB, Sanhedrin 99b; Mişne Tora, Hilhot Teşuva 3: 6-8, J. Abelson, "Maimonides on the Jewish Creed", The Jewish Quarterly Review 19:1 (1906), s. 46; Louis Isaac Rabinowitz, "Apikoros", Encyclopedia Judaica (Second Edition), ed. Fred Skolnik, Thomson Gale, 2007, II: 255-6.

30 Bitki koparan anlamına gelen bu tabir Talmud'da (Hagiga 14b-15a) Tannaim'den Elişa ben Abuyahu için kullanılmaktadır. Rabbani gelenekte özel olarak Tevrat'ın emirlerini öğrendiği halde yerine getirmeyenler için kullanılan bu ifade daha sonra en genel anlamıyla heretikleri nitelemek için tercih edilen bir kavram olmuştur.

31 İbn Meymun, Şerhu'l-Mişna, Sanhedrin 10.1, IV: 216

32 Kellner, Dogma in Medieval Jewish Thought, ss. 108-157, 179-184.

33 Marc Shapiro, "Maimonides' Thirteen Principles: The Last Word in Jewish Theology?", The Torah u-Madda Journal 4 (1993), s. 28.

34 Marc Shapiro, “Ani Maamin”, Encyclopedia Judaica (Second Edition), ed. Fred Skolnik, Thomson Gale, 2007, II: 165. En azından İbn Meymun'un bu listeyi Arapça kaleme aldığı bilindiği için listenin İbranice "Ani Maamin" diye başlamayacağı açıktır. Diğer taraftan "Ani maamin" ifadesinin Arapça orijinal metnin birebir İbranice çevirisi kabul etmek de mümkün değildir. Çünkü orijinal Arapça metinde "ben inanırım ki" anlamını karşılayacak bir ifade kullanılmamaktadır. Abraham Melammed makalesinde bugün itibariyle elimize ulaşan ulaşan Judeo-Arabic orijinal metinlerde bulunmayan bu ifadenin El-Harizi'nin çevirisi aracılığıyla yaygınlaştı̆̆ını iddia etmektedir. Bkz. Abraham Melammed, "Maimonides'Thirteen Principles: From Elite to Popular Culture", The Cultures of Maimonideanism, ed. James Robinson, Brill, 2009, ss. 184-190. 
$\mathrm{Bu}$ şekilde bir düzenlemede Hıristiyan geleneğinde yaygın olan "ben inanırım ki" veya "biz inanırız ki" şeklinde başlayan kredoların ${ }^{35}$ etkisinin olması muhtemeldir. İbn Meymun, Delâletü 'l-Hâirîn'de Tanrının varlığını, birliğini, cisim olmayışını ve kıdem'ini imanın konusu değil, bilginin konusu olarak izah etmektedir. O yüzden bu ifadelerin başında "ani maamin" ifadesinin olması İbn Meymun'un bu konudaki genel düşüncesiyle uyumlu bulunmamıştır. ${ }^{36}$

Yukarıda bahsedilen anonim çalışmanın dışında İbn Meymun'un listesine dayanılarak başka düzenlemeler de yapılmıştır. On dördüncü yüzyılın ilk yarısında Daniel ben Yahuda Ha-Dayan tarafindan düzenlenen "Yigdal" adlı ilahi bunlardan biridir. ${ }^{37}$ İbn Meymun'un iman esaslarını sistematik bir biçimde sunması, gerek kendisinden sonraki asırlarda iman esasları hazırlayan bilginler için gerekse şiir formunda sinagog ilahileri düzenleyen Yahudiler için temel başvuru kaynağı olmuştur. ${ }^{38}$

İbn Meymun'u iman esasları listesi hazırlamaya iten sebep nedir? Bu sorunun cevabını kesin olarak vermek mümkün olmasa da birkaç ihtimal üzerinde durulabilir. İbn Meymun bu listeyi, gelecek dünyadan nasibi olmayanların zikredildiği Mişna cümlesini ${ }^{39}$ şerh ederken sıralamaktadır. Onun ifadelerinden, Mişna cümlesini bu listeyi sunmak için uygun bir firsat olarak gördüğü anlaşılmaktadır. İbn Meymun'un iman esaslarını sıralamadan hemen önce kullandığ 1 "Burada zikredilmesi gerekir -ki bahsi için en uygun yer de burasıdır-, şeriatımızın usul ve kaideleri on üçtür" cümlesi de bunu teyit etmektedir. İbn Meymun'u iman esasları listesi hazırlamaya iten bir diğer neden dinî bir otorite olarak Yahudi halkını eğitme (irşad) amacı olabilir. Ortadoğu, Kuzey Afrika ve Avrupa'daki değiş̧ik Yahudi cemaatlerinden kendisine gönderilen mektuplar ve sorulan sorular dikkate alındığında, yaşadığı dönemde İbn Meymun’un

35 Örneğin İznik ve Havariler kredosu.

36 Rafael Yaspa, Filosofya Yahudit be-Yemey Ha-beynayim:Ha-Rambam, Ha-Universita Ha-Ptuha, 2005 , ss. $58-59$.

37 Jacob Neusner\&Alan J. Avery-Peck, "Yigdal", Dictionary of Judaism, Routledge, 2004, s. 175; İbn Meymun'un listesiyle Ani Maamin ve Yigdal ilahilerinin oluşumu ve etkileşim süreci ile ilgili bkz. Abraham Melammed, "Maimonides' Thirteen Principles: From Elite to Popular Culture", The Cultures of Maimonideanism, ed. James Robinson, Brill 2009, ss. 171-190; Admiel Kosman, "Yud-Gımel İkkarim le-Rambam be-Peruş Ha-Mişna be-Piyutey Yigdal ve Ani Maamin", Sefer Yovel Minha Le-iş Rav Simon Dolgin, ed. Itamar Wahrhaftig. Yeruşalayim 1991, ss. 337-348; Moshe Goshen-Gottestein, Yud-Gımel İkkarim Le-Ha-Rambam be-Targum El-Harizi, Tarbits 26 (1957), ss. 185-196.

38 İman esasları listesi olarak hazırlanmış ilahiler için bkz. Alexander Marx, "A List of Poems on the Articles of the Creed", Jewish Quarterly Review 9 (1918-9), ss. 305-336.

39 Sanhedrin 10.1 
Yahudilerin dinî otoritesi olduğunda şüphe yoktur. $\mathrm{Bu}$ amaç doğrultusunda $\mathrm{o}$, Rabbani literatürde dağınık ve parça parça zikredilen esasları bir araya getirerek Yahudi halkına sunmak istemiş olabilir.

İbn Meymun'u bu esasları listelemeye sevkeden bir diğer ihtimal de İslâm ve Hıristiyanlığa karşı reddiye yazma ihtiyacıdır. O, Yemen Mektubu'nda İslâm'1 ve Hıristiyanlığı mermerden, odundan, gümüşten veya altından yapılmış insan heykeline benzeterek bu dinlerin Yahudilikten kopya olduğunu ifade etmektedir. ${ }^{40}$ İbn Meymun'un listesinde Hıristiyanlığa veya İslâm'a ya da ikisine birden göndermeler olduğunu görmek mümkündür. Bu çerçevede nesh maddesinin İslâm'a reddiye olarak listede yer aldığı açıktır. Ayrıca İbn Meymun'un Musa şeriatının geçerliliğini vurgulaması bu iki dine cevap niteliği taşımaktadır. ${ }^{41}$

Yahudi din bilginlerinin yaşadıkları dinî ve kültürel ortam, hazırladıkları listelerdeki bazı maddelerde etkisini göstermektedir. Bu çerçevede İbn Meymun'un nesh maddesini listeye almasında İslâm toplumunun etkisi olduğu açıktır. İbn Meymun'un listesindeki ölülerin diriltilmesi maddesini de dinî ve kültürel ortamla ilişkilendirenler bulunmaktadır. Kaynakların naklettiğine göre başta Babil gaonları olmak üzere devrin ileri gelen bazı Yahudi bilginleri İbn Meymun'u ölülerin diriltileceğine inanmamakla suçlamışlardır. İbn Meymun kendisine yöneltilen bu eleştirilere cevap niteliğinde 1191 yılında "Makale fi Thiyat Ha-Metim (Ölülerin Diriltilmesi Hakkında Risale)" adıyla bir çalışma kaleme almıştır. İbn Meymun'un eserlerinin geneline bakıldığında ölülerin bedenen diriltilmesinden ziyade ahiret inancına vurgu yaptığı görülmektedir. Bundan dolayı bazı araştırmacılar İbn Meymun'un ölülerin diriltilmesi konusunda zihninin net olmadığını, buna rağmen bu maddeyi listeye aldığını dile getirmişlerdir. ${ }^{42}$

40 İbn Meymun, İggeret Teyman, ed. Abraham Şlomo Halkin, American Academy for Jewish Research, New York 1952, s. 14.

41 Solomon Schechter, “Dogmas of Judaism”, Studies in Judaism, Gorgias Press, 2003, ss. 217-218.

42 Lea Naomi Goldfeld, Moses Maimonides' Treatise on Resurrection: an Inquiry into Its Authenticity, Ktav Pub Inc., 1986, ss. 27-28; Rafael Yaspa, Filosofya Yahudit be-Yemey Ha-beynayim:Ha-Rambam, Ha-Universita Ha-Ptuha, 2005, ss. 41-42, Daniel Jeremy Silver, Maimonidean Criticism and the Maimonidean Controversy 1180-1240, Brill, 1965, ss. 109-135, T.M. Rudavsky, Maimonides, WileyBlackwell Pub., 2010, ss. 105-106; Moșe Halbertal, Ha-Rambam, The Zalman Shazar Center Pub., Yeruşalayim 2009, ss. 126-131; Robert S. Kirschner, "Maimonides' Fiction of Resurrection." Hebrew Union College Annual 52 (1981), ss. 163-93. 


\section{Sonuç}

Yukarıda zikredildiği üzere ortaçağ boyunca birçok Yahudi din bilgini iman esasları listesi hazırlamıştır. Listelerdeki maddelere göz atıldığında Yahuda Hadassi'nin (Karaî) İbranice ile ilgili maddesi, David ben Samuel Kohavî'nin felsefî ilimlerin tahsili ile ilgili maddesi, İsrail ben Samuel Mağribî’nin (Karaî) kıble ile ilgili maddesi ve Hasday Crescas'in Urim ve Tumim ile ilgili maddesi istisna tutulacak olursa, listelerin birbirinin tekrarı olduğu görülmektedir.

İbn Meymun'un listesinde ise diğerlerinden farklı olarak nesh maddesi dikkat çekmektedir. Bu da içinde yaşadığı Müslüman topluma cevap verme ihtiyacından kaynaklanmaktadır. İbn Meymun, listelediği esaslara bağlayıc1lık atfetse de onun bu hükmü karşılık bulmamıştır. İbn Meymun'un listesi sonraki asırlarda Yahudi din bilginleri tarafından eleştirilmiş ve yeni liste denemeleri yapılmıştır. Bu da Yahudi din bilginlerin İbn Meymun'un listesi ile yetinmediklerini ve bağlayıcılığını kabul etmediklerini göstermektedir. Bununla birlikte bütün eleştirilere ve alternatif liste düzenlemelerine rağmen İbn Meymun'un listesinin günümüzde en fazla kabul gören liste olduğu da tartışma götürmez bir gerçektir.

\section{KAYNAKÇA}

Abelson, Joshua, "Maimonides on the Jewish Creed", The Jewish Quarterly Review 19:1 (1906), ss. 24-58.

Abravanel, Yitshak, Roş Amana, Warsaw 1881.

Albo, Yosef, Sefer Ha-Ikkarim, ed. Isaac Husik, Jewish Publication Society, 1946 (5 Cilt).

Altmann, Alexander, “Articles of Faith”, Encyclopedia Judaica (Second Edition), ed. Fred Skolnik, Thomson Gale, 2007, II: 529-532.

Arama, Yitshak, Akedat Yitshak, ed. Hayyim Yosef Pollak, Lvov 1868.

Astruc, Abba Mari, Minhat Kinaot, ed. M. J. Bisseliches, Pressburg 1838.

Ben-Shammai, Haggai, “Asarat İkkarey Emuna şel Rav Saadya Gaon”, Daat 37 (1996), ss. 11-26.

Baybal, Sami, "Saadia Gaon, Onun Ortaçağ Yahudi Felsefesini Oluşturma ve Yahudi Dogmasını Yeniden Formule Etme Çabaları", Selçuk Üniversitesi Illahiyat Fakültesi Dergisi 15 (2003), ss. 169-189.

Crescas, Hasday, Or Adonay, ed. Shlomo Fisher, Sifrey Ramot, Yeruşalayim 1990. 
Delmedigo, Eliyahu, Behinat Ha-Dat, ed. Isaac Samuel Reggio, Wien 1833.

Doğan, Hatice, Maymonides 'in Hayatı ve Eserleri, Gözlem Gazetecilik Basın ve Yayın AŞ., İstanbul 2010.

Duran, Şim'on ben Tsemah, Ohev Mişpat, Venetsia 1589.

Freundel, Barry, "Dogmas, Beliefs and Creeds", Contemporary Orthodox Judaism's Response to Modernity, Ktav Publishing House, 2004, ss. 110-121.

Feyyumî, Said bin Yusuf (Saadya Gaon), Peruşey Rabbenu Saadya Gaon al Ha-Tora, ed. Yosef Kafih, Mosad Rav Kook, Yeruşalayim 1963. , Kitabu'l-Emanât ve'l-İtikâdât, ed. S. Landauer, Leiden, 1880.

Goldfeld, Lea Naomi, Moses Maimonides'Treatise on Resurrection: an Inquiry into Its Authenticity, Ktav Pub Inc., 1986.

Goshen-Gottestein, Moshe, "Yud-Gımel İkkarim Le-Ha-Rambam be-Targum El-Harizi”, Tarbits 26 (1957), ss. 185-196.

Hadasi, Yahuda, Eşkol Ha-Kofer, Gözleve 1836.

Halbertal, Moşe, Ha-Rambam, The Zalman Shazar Center Pub., Yeruşalayim 2009.

Halkin, Abraham Shlomo, "A Karaite Creed", Studies in Judaica, Karaitica and Islamica, Ed. Sheldon R. Brunswick, Bar Ilan University Press, Israel 1982, ss. 145-153.

Hyman, Arthur, "Maimonides' Thirteen Principles", Jewish Medieval and Renaissance Studies, ed. Alexander Altmann, Cambridge 1967.

İbn Davud, Abraham, Ha-Emuna Ha-Rama, ed. Simson Weil, Frankfurt am Main 1852 (Yeni basım, Yeruşalayim 1967).

İbn Meymun, Musa, Mishnah im Perush Rabbenu Moshe ben Maimon (Şerhu'l-Mişna), ed. Yosef Kafih, Mosad Ha-Rav Kook, Yeruşalayim 1963-1968 (7 cilt).

, Iggeret Teyman, ed. Abraham Shlomo Halkin, American Academy for Jewish Research, New York 1952.

, Delâletü'l-Hâirîn, tahk. Hüseyin Atay, Ankara Üniv. İlahiyat Fak. Yy., Ankara 1974.

Kellner, Menachem, Dogma in Medieval Jewish Thought, Oxford University Press, 1986.

Kirschner, Robert S., "Maimonides' Fiction of Resurrection." Hebrew Union College Annual 52 (1981), ss. 163-93. 
Kohavi, David ben Samuel, Migdal David: Sefer Ha-Emuna, ed. Moshe Hirschler, Yeruşalayim 1983.

Kosman, Admiel, "Yud-Gımel İkkarim le-Rambam be-Peruş Ha-Mişna bePiyutey Yigdal ve Ani Maamin", Sefer Yovel Minha Le-iş Rav Simon Dolgin, ed. Itamar Wahrhaftig, Yeruşalayim 1991, ss. 337-348.

Mainz, Ernest, "The Credo of a Fourteenth Century Karaite", Proceedings of the American Academy for Jewish Research 22 (1953), ss. 55-63.

Marx, Alexander, "A List of Poems on the Articles of the Creed", Jewish Quarterly Review 9 (1918-9), ss. 305-336.

Melammed, Abraham, "Maimonides' Thirteen Principles: From Elite to Popular Culture", The Cultures of Maimonideanism, ed. James Robinson, Brill 2009, ss. 171-190.

Neusner, Jacob\& Avery-Peck, Alan J., "Yigdal”, Dictionary of Judaism, Routledge, 2004, ss. 175-6.

Philo, On the Creation of the Cosmos (De Opificio Mundi), İngilizce'ye çeviren C.D. Younge, 1890.

, On the Creation of the Cosmos according to Moses, İngilizce'ye çeviren D.T. Runia, Brill 2001.

Rabinowitz, Louis Isaac, "Apikoros", Encyclopedia Judaica (Second Edition), ed. Fred Skolnik, Thomson Gale, 2007, II: 255-6.

Rudavsky, T.M., Maimonides, Wiley-Blackwell Pub., 2010.

Schechter, Solomon, Studies in Judaism, Gorgias Press, 2003

Schur, Nathan, "Creed", Karaite Encyclopedia, Peter Lang Pub Inc., 1995, s.74.

Shapiro, Marc, “Ani Maamin”, Encyclopedia Judaica (Second Edition), ed. Fred Skolnik, Thomson Gale, 2007, II: 165.

, 'Maimonides' Thirteen Principles: The Last Word in Jewish Theology?", The Torah U-Madda Journal 4 (1993), ss. 187-242.

, The Limits of Orthodox Theology: Maimonides'Thirteen Principles Reappraised, Littman Library of Jewish Civilization, 2004.

Silver, Daniel Jeremy, "The Resurrection Debate", Maimonidean Criticism and the Maimonidean Controversy 1180-1240, Brill 1965, ss. 109135.

Yaavets, Yosef ben Hayim, Yasod Ha-Emuna, Warsaw 1871. 
, Maamar Ha-Ahdut, Warsaw 1871.

Yaspa, Rafael, Filosofya Yahudit be-Yemey Ha-Beynayim: Ha-Rambam, HaUniversita Ha-Ptuha, Telaviv 2005.

\section{Ek}

\section{Yahudi Şeriatı'nın Usul ve Kaideleri ${ }^{43}$ \\ וממא ינב אן אדכרה הנא, והדא אחק מוצע בדכרה, אן אצול שריעתנא וקואערהא תלת עשרה קאערה.}

Burada zikredilmesi gerekir ki ,bahsi için en uygun yer de burasıdır ,şeriatımızın usul ve kaideleri on üçtür.

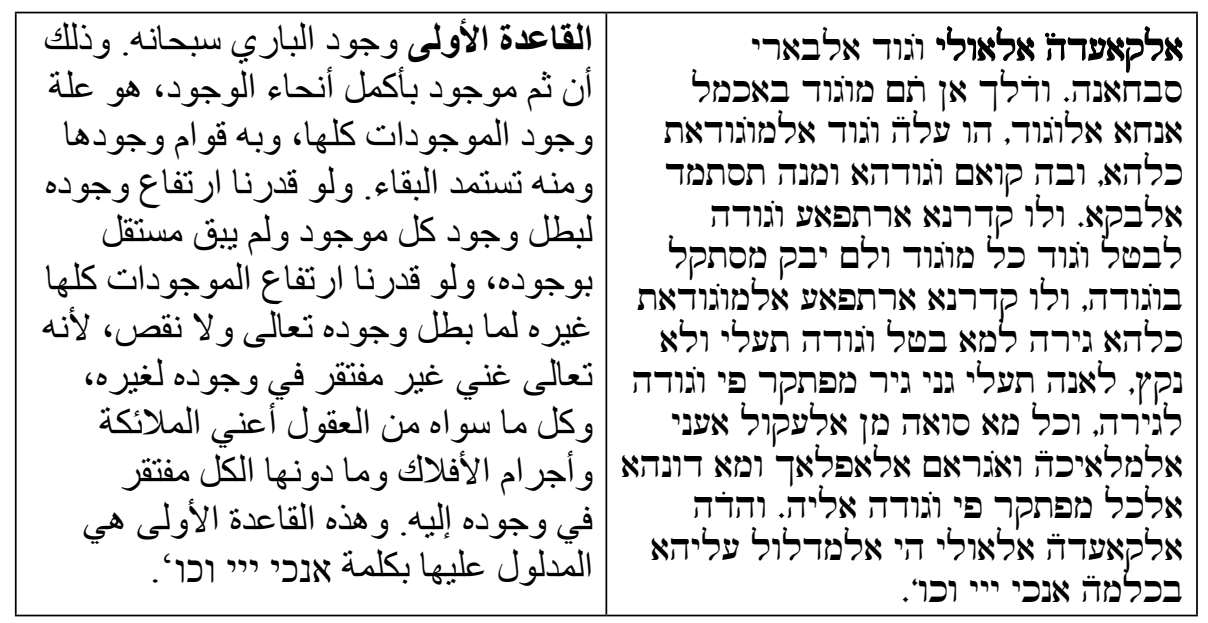

Birinci kaide: Şanı yüce Yaratıcının varlığıdır. Varlığın en mükemmel haliyle mevcut olan o, bütün mevcudatın varlık sebebidir, herşey onunla ayakta durur ve varlığını onun sayesinde devam ettirir. Eğer onun mevcudiyetini kaldırdığımızı varsaysak, mevcut olan bütün herşeyin varlığı biter ve hiçbir şey tek başına varlığını devam ettiremezdi. Onun dışında bütün mevcudatı yok saysak,

43 İbn Meymun, Şerhu'l-Mişna, Sanhedrin 10.1-2, IV: 210-216. Türkçe tercümede parantez içinde kullanılan kelimeler anlam bütünlüğünü koruma amacıyla tarafımızdan eklenmiştir. Yine metinde müellifin konudan biraz saptığını veya çok detaya girdiğini düşündüğümüz birkaç kısım atlanmış ve bu yerler ard arda noktalarla verilmiştir. Ayrıca ihtiyaç duydukça dipnotlar eklenerek konunun açıklığa kavuşması amaçlanmıştır. Tanah'tan yapılan alıntılarda aksi belirtilmediği müddetçe Kitabı Mukaddes Şirketi'nin yeni çevirisi kullanılmıştır. İbranice olan kısım Judeo-arabic orijinal metin olup, diğer kısım da okuyuculara kolaylık için Arap harfleri transkripsiyonuyla verilmiştir. Tanah’tan yapılan alıntılar ile düşünürün İbranice olarak kullandığı kavramlar ve Tevrat ayetleri Arapça transkripsiyon bölümünde de orijinal şekliyle korunmuştur. Arap harfleriyle yazılan kısımda sadece Tora yerine Tevrat veya Moşe Rabenu yerine seyyidina Musa gibi kelimeler tercih edilerek akıcılığın sağlanması amaçlanmıştır. 
şanı yücenin varlığı yok olmaz ve eksilmez. Çünkü yaratıcı, varlığını kendisi dışındakilere borçlu olmaktan müstağnidir. Onun dışında akıllar yani melekler, feleklerin ecramı ve bunların dışındaki herşey mevcudiyetini ona borçludur. Ve bu birinci kaideye "Ben Tanrı Rab'bim..." ${ }^{44}$ ifadesiyle işaret edilmiştir.

\begin{tabular}{|c|c|}
\hline 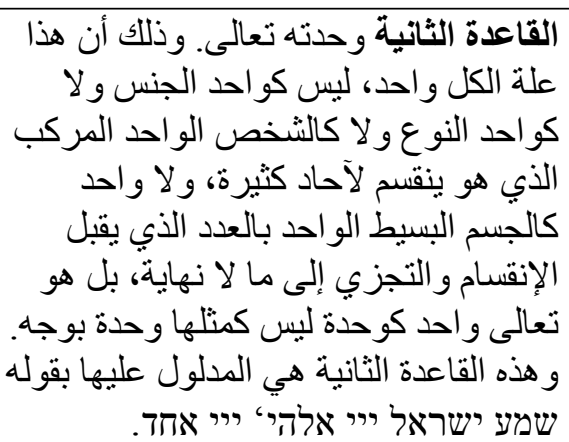 & 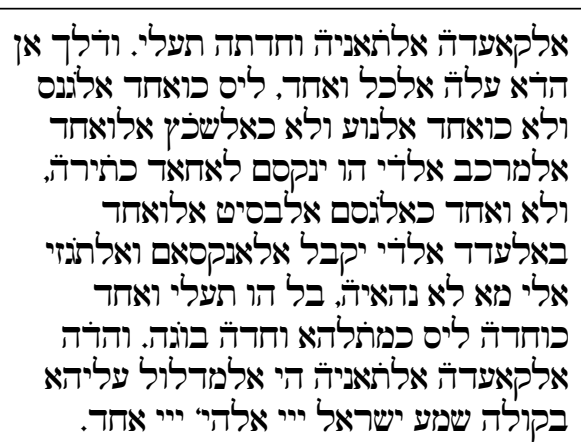 \\
\hline
\end{tabular}

İkinci kaide: Yaratıcının birliğidir. $\mathrm{Bu}$, her şeyin illeti o tek olan (ilah) dır, anlamına gelir. Onun "bir"liği ne cins ve türün, ne birçok birlere ayrılan mürekkeb bir şahsın ne de sayısal bakımdan sonsuz sayıda bölünmeyi ve parçalara ayrılmayı kabul eden basit bir cismin birliği gibidir. Bilakis o, (herhangi bir yönden) birliği hiçbir şeye benzemeyen bir'dir. Bu ikinci kaideye "Dinle,

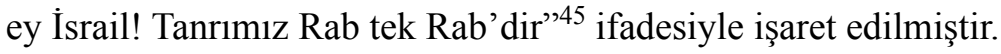

\begin{tabular}{|c|c|}
\hline 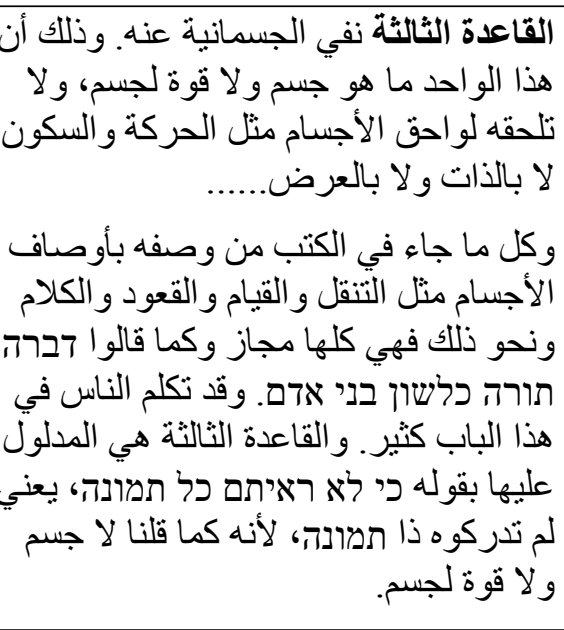 & 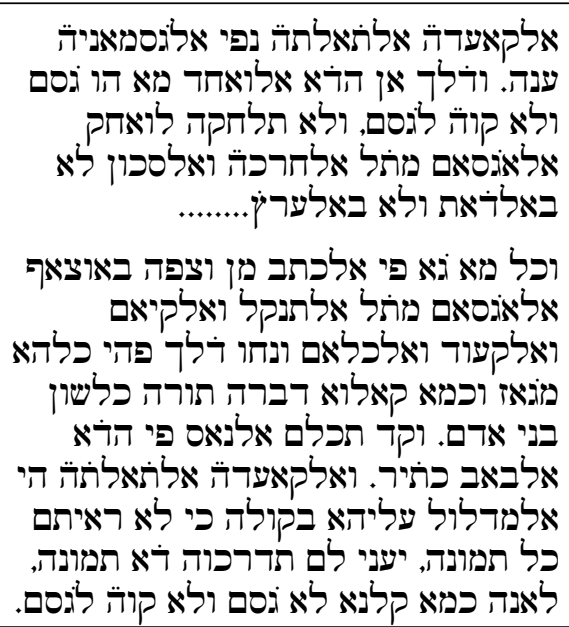 \\
\hline
\end{tabular}

44 Çıkış 20.2; Tesniye 5.6

45 Tesniye 6.4 
Üçüncü kaide: Yaratıcının cismaniyetini reddetmektir. Yani bir olan yaratıcı ne cisimdir ne de cisimde kuvvedir. Ne zat olarak ne de araz olarak hareket etme ve durma gibi cismanî özellikler ona atfedilemez.

Kitaplarda geçen yer değiştirme, ayağa kalkma, oturma, konuşma ve buna benzer cismanî vasıfların tamamı mecazdır. Din bilginlerinin dedikleri gibi “Tevrat, insanoğlunun diliyle konuşmuştur" ${ }^{26}$. İnsanlar bu konuda çok sözler sarfettiler. Üçüncü kaideye "Rab Horev'de ateşin içinden size seslendiği gün hiçbir suret görmediniz" ${ }^{\text {47 }}$ ifadesiyle işaret edilmiştir. Yani (Tanrı'nın) hiçbir sureti görülmemiştir. Çünkü dediğimiz gibi ne cisimdir ne de bir cisimde kuvvedir.

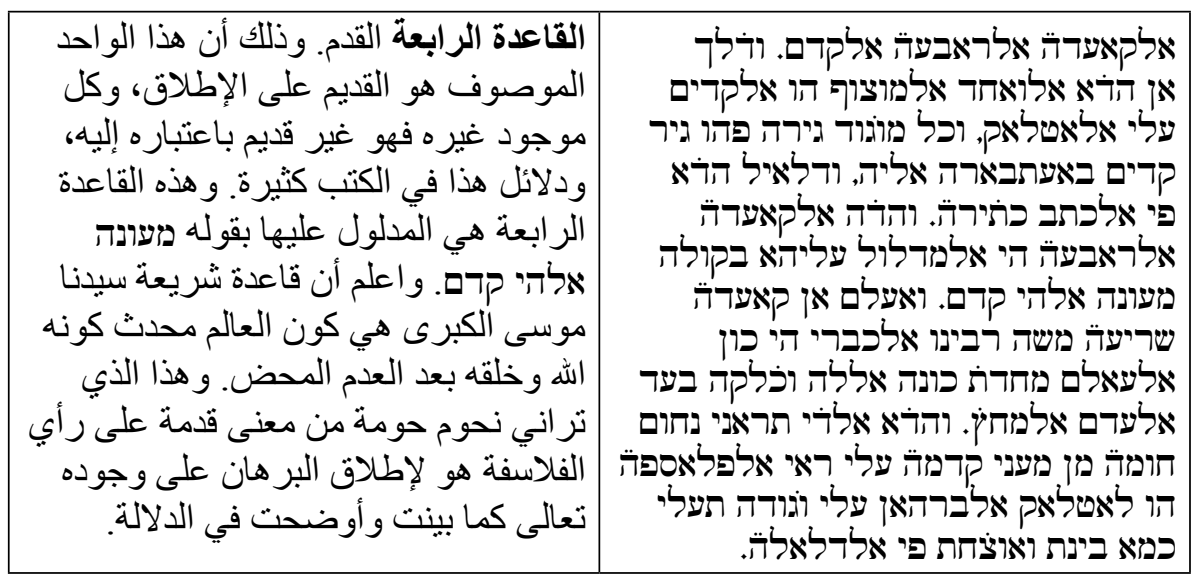

Dördüncü kaide: Kıdem'dir. Herhangi bir yönden kayıt altına alınmaksızın "kadîm" olarak vasıflandırılan "bir"dir. Onun dışındaki her şey ona itibarla kadîm değildir. Kitaplarda bunun delilleri çoktur. Bu dördüncü kaideye "Sığınağın kadîm olan Tanrı'dır." 48 ifadesiyle işaret edilmiştir. Bil ki Musa efendimizin yüce şeriatına göre alem muhdes'tir. Allah onu, sırf yokluktan oluşturmuş ve yaratmıştır. Alemin kıdemi mevzuunda felsefecilerin görüşlerine sık sık değindiğimi göreceksin. Delâletü'l Hairîn'de ${ }^{49}$ ifade edip açıkladığım gibi alem, yaratıcının mevcudiyetine kesin bir delildir.

$46 \mathrm{~TB}$, Brahot $31 \mathrm{~b}$

47 Tesniye 4.15

48 Tesniye 33.27, Türkçe Kitabı Mukaddes çevirileri bu ifadeyi "Sı̆̆ıınağın çağlar boyu var olan Tanrı'dır" ifadesiyle çevirmektedirler. İbranice orijinal ifadede de kadim kelimesi ile aynı kökten gelen kelime kullanıldı̆̆ için bu şekilde mana verdik.

49 Elimizdeki bilgilere göre İbn Meymun, Delâletü 'l-Hâirîn adlı eserini bu kaideleri sıraladığı Şerhu'l-Mişna adlı eserinden sonra kaleme almıştır. Fakat yazarın ömrünün sonuna kadar eklemeler yaparak eserini geliştirdiği bu yüzden de birkaç değişik nüshanın ortaya çıktığı bilinmektedir. Bu yüzden Delâletü'l-Hâirîn'e atıf yaptığı bu kısım da Delâletü'l-Hâirîn'den sonra kaleme aldığı nüshada yer almaktadır. 


\begin{tabular}{|c|c|}
\hline 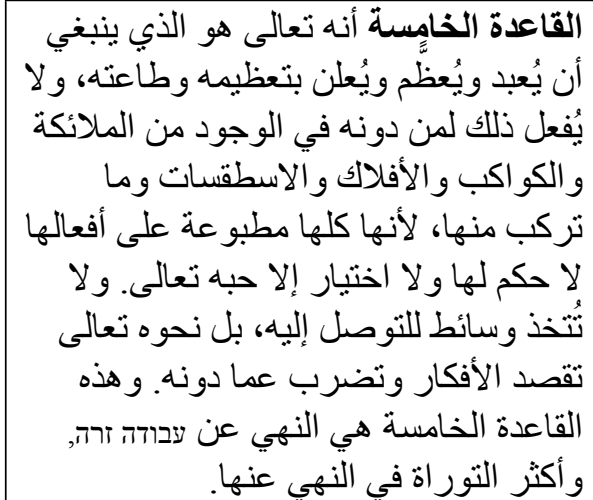 & 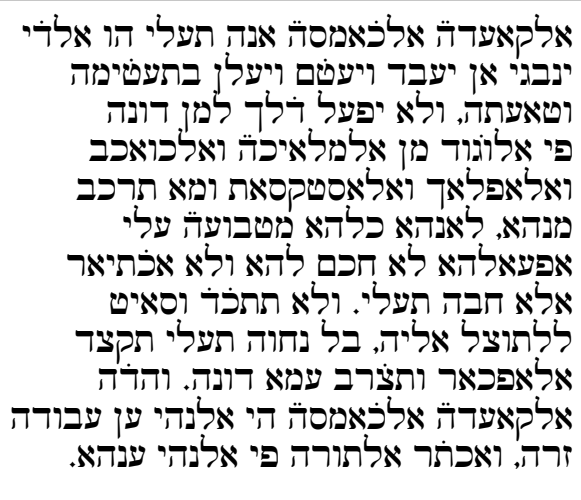 \\
\hline
\end{tabular}

Beşinci kaide: Yaratıcı kendisine ibadet edilmesi, yüceltilmesi, tazim ve itaat duyulması gerekendir. Bunlar varlık aleminde bulunan meleklerden, yıldızlardan, gök cisimlerinden, elementlerden ve onları oluşturan şeylerden hiçbiri için yapılmaz. Çünkü onlar fiillerine bağlıdırlar ve onların güçleri, seçme durumları yoktur, ancak (onların bütün işleri) yaratıcının sevgisiyledir. Ona ulaşmak için aracılar edinmeye gerek yoktur, bilakis fikirler ona yönelir ve onun haricindekilerden uzaklaştırılır. Bu beşinci kaide şirkten nehy'dir, Tevrat'ın çoğu da şirkten nehy'den bahseder.

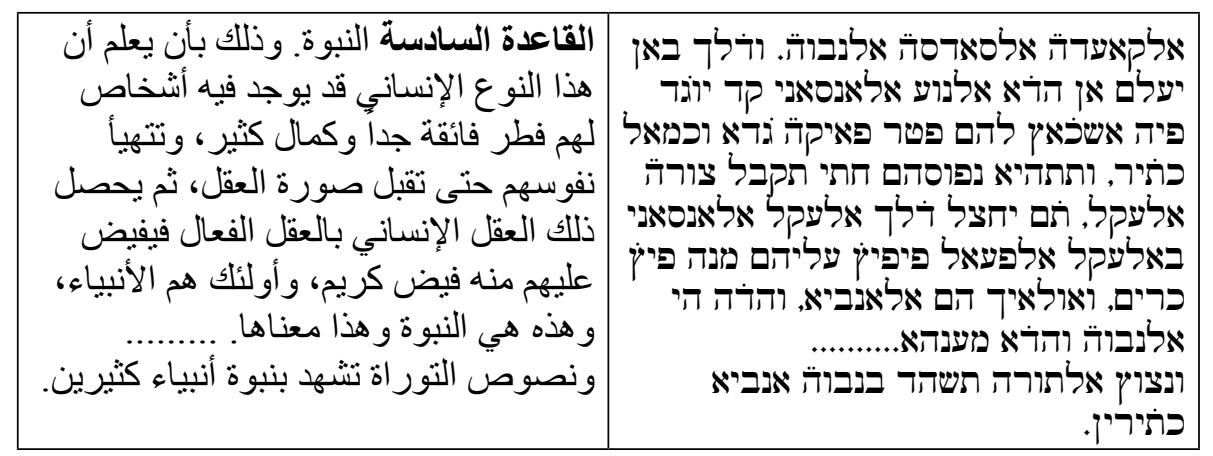

Altıncı kaide: Nübüvvettir. Bilinmelidir ki insan türü içerisinde gerçekten çok yüksek fitrata ve kemâle sahip şahıslar mevcuttur. Nefisleri öyle gelişir ki, akıl suretini alır. Sonra (akıl suretini almış) insan aklı, faal akıl ile birleşir ve ondan o şahıslara büyük feyizler akar. İşte onlar peygamberlerdir. İşte bu peygamberliktir, bu da onun manasıdır... Tevrat'ın ayetleri bir çok peygamberden bahseder. 
القاعدة السابعة نبوة سيدنا موسى. وذلك

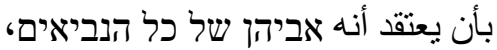

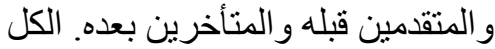
هم دونه في الرتبة، وهو صفو الله من الهن

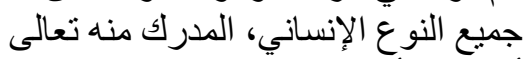

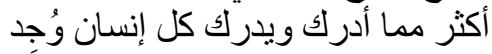

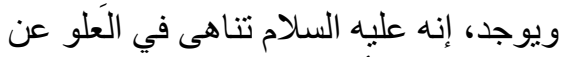

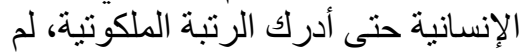
يبق له حجاب إلا وخرقه، و لا عاقه عائق الانق

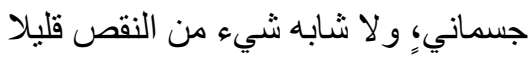
و لا كثيرا.

فأقول أن نبوة موسى انفصلت عن نبوة جملة الأنبياء بأربعة فصول فولى انفول.

الفصل الأول أن أي نبي كان لا يكلمه اله إلا

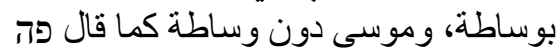
אל פה אדבר בו.

و الفصل الثاني، أن كل نبي لا يأتيه الوحي

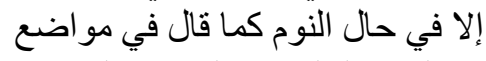
בחלום הלילה, ויחלום, בחלום בחזיון

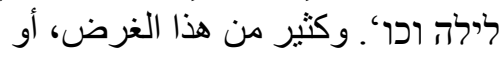

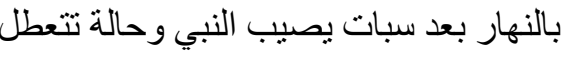
فيها حو اسه و تخلي فكرته شبه نوم، و هذه

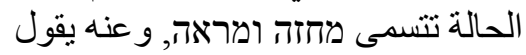
במראות אלהים. وموسى يأثبه الخطاب بالنهار وهو עומד בין שני הכרובים كما و عده اله ונועדתי לך שם ודברתי אתך עופר

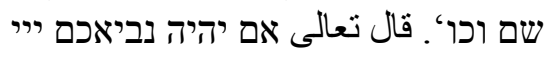

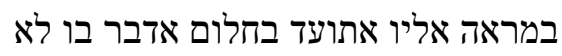
כן עבדי משה.

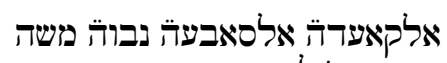
רבינו. ודלך באן יעתקד אנה אבעה אביהן משתי

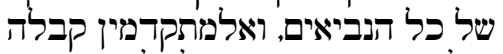

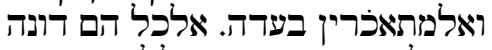

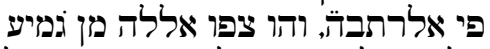

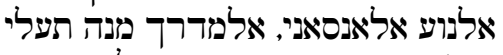

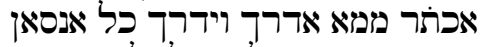

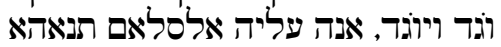

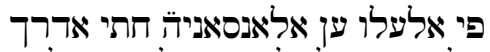

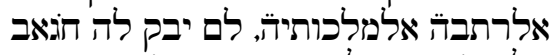

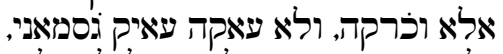
ולא שאבה שי פן אלנקיא ולאי קלילא ולאיא ינסיאי כתירא...

פאקול אן נבוה משה אנפצלת ען נבוה גמלה אלאנביא בארבעה פצול.

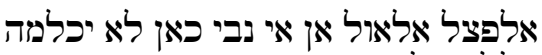

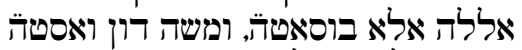
כמא קאל פה אל פה אדבר בו.

ואלפצל אלתאני, אן כל נבי לא יאתיה

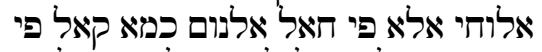

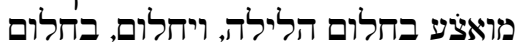

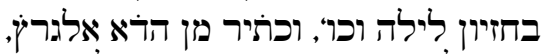
או באלנהאר בעד סבאת יצירוך וסתיב אלנבי

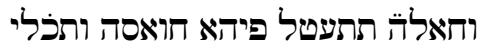

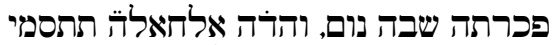

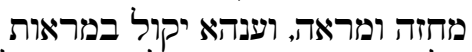

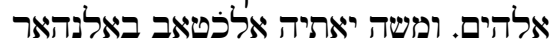

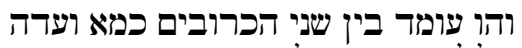

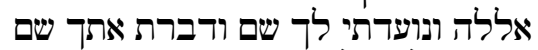

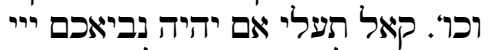
במראה אליו אתועד בחלום ארבר בו יחי ליא כן עבדי משה. 


\begin{tabular}{|c|c|}
\hline 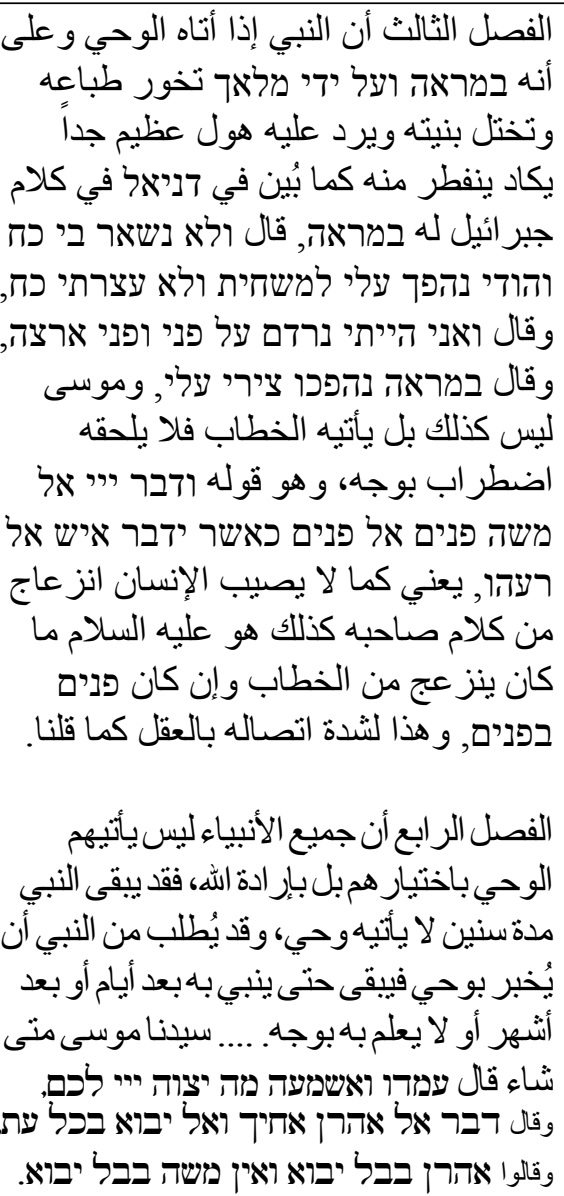 & 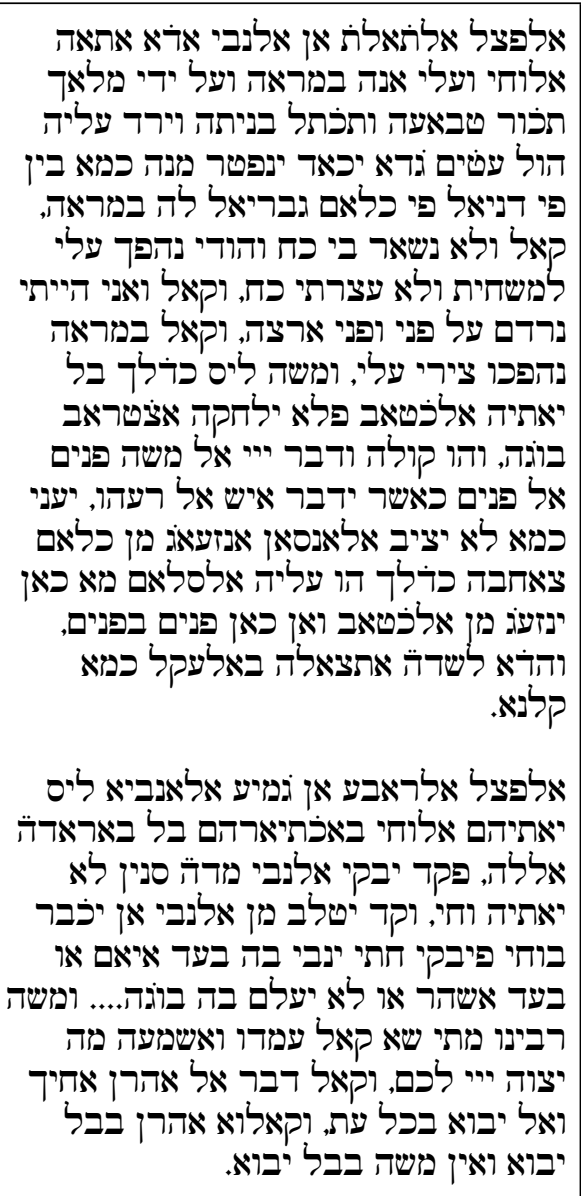 \\
\hline
\end{tabular}

Yedinci kaide: Musa Efendimizin peygamberliğidir. Onun kendisinden önceki ve sonraki bütün peygamberlerin babası (en büyüğü) olduğuna inanı1malıdır. Bütün peygamberler rütbe bakımından ondan düşüktürler. $\mathrm{O}$, bütün insan türünden Allah'ın seçtiğidir. O, gelmiş ve gelecek bütün insanlar arasında Allah'ı en fazla idrak edendir. Yücelik bakımından insanlığın sonuna ulaşmış hatta melekût âleminin derecelerini de idrak etmiştir. Onun yırtmadığı perde kalmamıştır, hiçbir cismani engel de onu engelleyememiştir. Az ya da çok hiçbir eksiklik ona karışmamıştır.

Derim ki, Musa'nın peygamberliği diğer bütün peygamberlerin nübüvvetinden dört farkla ayrılır. 
Birinci fark: Allah her peygamber ile ancak bir aracı vasitasıyla konuşur. Musa ise "Ben onunla yüz yüze konuşurum" $" 50$ buyrulduğu gibi aracısız konuşur.

İkinci fark: Her nebiye vahiy (Tevrat'ta) değişik yerlerde "gece düşü"51 "düş gördü"52 "gece vizyonunda/görümünde" 53 ifadeleriyle buyrulduğu gibi ancak uyku halinde gelir veya gündüz vakti peygambere isabet eden derin uykudan sonra gelir ki o durumda hisleri etkisizleşmiş ve fikriyatı uykudaymış gibi boş olur. Bu durum mahaze ve mar'e olarak isimlendirilir ve "Tanrı'dan gelen görümlerde" ${ }^{54}$ ifadesinde buna işaret edilir. Musa'ya ise hitap Allah'ın ona "Orada seninle buluşacak ve seninle konuşacağım" 55 diye vaat ettiği gibi gündüz vakti iki keruv'un ${ }^{56}$ arasında ayakta dururken gelir. Yaratıcı buyurmuştur ki "Eğer aranızda bir peygamber varsa, Ben Rab görümde kendimi ona tanıtır, onunla düşte konuşurum. Ama kulum Musa öyle değildir."

Üçüncü fark: Görüm şeklinde veya bir melek aracılığıyla bir peygambere vahiy geldiğinde gücü zayıflar, bünyesi sarsılır ve çok şiddetli korku duyar. Vahiyden ötürü parçalanacak gibi olur. Daniel'de (bu gerçeğe) Cebrail ona konuştuğunda "(Bu büyük görümü seyrederken) gücüm tükendi, benzim büsbütün soldu, kendimi toparlayamadım. Yüzüstü yere düşüp derin bir uykuya daldım"58 ve "Ey efendim, bu görüm yüzünden acı çekiyorum, kendimi toparlayamıyorum." $" 59$ ifadeleriyle işaret edilmiştir. Musa ise böyle değildir, bilakis ona hitap geldiğinde herhangi bir şekilde ıstırap duymaz. Yaratıcı buyurmuştur ki "Rab Musa'yla iki arkadaş gibi yüz yüze konuşurdu" ${ }^{60}$. Yani bir insan arkadaşıyla konuşurken nasıl endişe duymuyorsa aynı şekilde o da -selam üzerine olsun- yüz yüze bile olsa hitaptan kaygılanmıyordu. Bu da bahsettiğimiz gibi akıl ile olan güçlü irtibatından kaynaklanmaktadır.

Dördüncü fark: Bütün peygamberlere vahiy kendi isteklerine göre değil Allah'ın dilemesine göre gelir. Bir peygamber yıllarca bekler ama vahiy

50 Say1lar 12.8

51 Tekvin 20.3

52 Tekvin 28.12

53 Eyüp 33.15

54 Hezekiel 8.3, 40.2

55 Çıkış 25.22

56 Tevrat'ta bahsedilen ruhani varlık. Tekvin 3.24; Çıkış 25.18,19,20,22; Sayılar 7.89

57 Say1lar $12.6-8$

58 Daniel 10.8

59 Daniel 10.16

60 Çıkış 33.11 
gelmez. Peygamberden kendisine iletilen vahyi duyurması istenir. O vahiyle günlerce aylarca kalabilir ve herhangi bir şekilde (yeni vahyin ne zaman geleceğini) bilemez. Musa efendimiz ne zaman dilese "“"Rabbin sizinle ilgili bana neler söyleyeceğini duyuncaya dek bekleyin"",61 derdi. Yine yaratıcı ona buyurmuştur ki “Ağabeyin Harun'a de ki: (Perdenin arkasındaki en kutsal bölüm'e) ikide bir girmesin."62 (Din bilginleri) demişlerdir ki "Harun oraya giremez ama bu yasak Musa için geçerli değildi”.

\begin{tabular}{|c|c|}
\hline هو & וני \\
\hline
\end{tabular}

61 Sayılar 9.8

62 Levililer 16.2 
Sekizinci kaide: Tevrat'in Allah'tan gelişidir (Allah'ın sözü/vahyi oluşudur). Şuna inanılmalıdır ki bugün elimizde bulunan bu Tevrat'ın tamamı Musa'ya indirilen Tevrat'tır ve onun tamamı Allah'tandır. Yani Tevrat Musa'ya Allah tarafindan mecaz olarak kelâm şeklinde ifade edilen bir yolla ulaşmıştır. Onun -selam üzerine olsun- dışında bu iletişimin nasıl olduğunu kimse bilemez. O ise yazıcı konumunda olup kendisine dikte ettirilir o da tarihleri, hikayeleri ve kuralları yazıp kaydeder. Bu yüzden kanun koyucu ${ }^{63}$ olarak adlandırılmıştır. "Ham'ın oğulları: Kûş, Misrayim, Pût, Kenan" ${ }^{64}$ ayeti ile "Karıs1 Matret'in k1zı Mehetavel'di" ${ }^{65}$ ayeti arasında, "Ben Tanr1 Rabbim"66 ile "Dinle ey İsrail! Tanrımız Rab tektir." 67 arasında bir fark yoktur. Hepsi Allah'tandır. Yaratıcının Tevrat'ının tamamı tam/bütün, pak, kutsal ve doğrudur. Din bilginlerinin gözünde Menaşşe, "Tevrat ağaç ve kabuktan (luzümsuz şeylerden) oluşmuştur, bu tarihlerin ve hikayelerin bir faydası yoktur ve Musa'nın derlemesidir" şeklindeki düşüncesinden ötürü küfür ve nifakta bütün kafirlerden daha azılı sayılmıştır. Bu ifadeler "Tevrat Allah'tan değildir" demektir. Din bilginleri “bütün Tevrat Allah’tandır, yalnızca şu (falanca) tek ayet hariç ki onu da yaratıcı değil Musa kendi ağzından söylemiştir şeklinde konuşanlar1 "Rabbin sözünü küçümsemiş" ${ }^{68}$ ayeti anlatmaktadır" demişlerdir. Yaratıcının şanı kafirlerin söylediklerinden yücedir. Bilakis Allah'ın anlayış nasip ettiği herkes için Tevrat'ın her harfi bir hikmet ve muhteşemlik barındırmaktadır. "Ölçüleri yeryüzünden uzun, denizden geniştir." 69 ayetinde denildiği gibi onun nihai hikmeti anlaşılamaz.

\begin{tabular}{|c|c|}
\hline 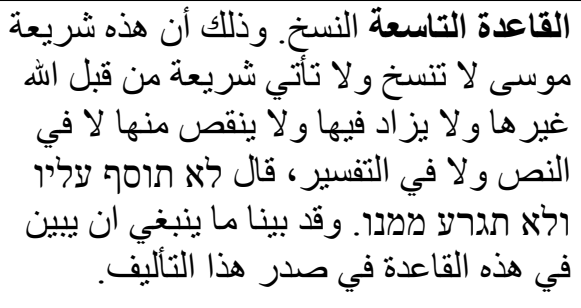 & 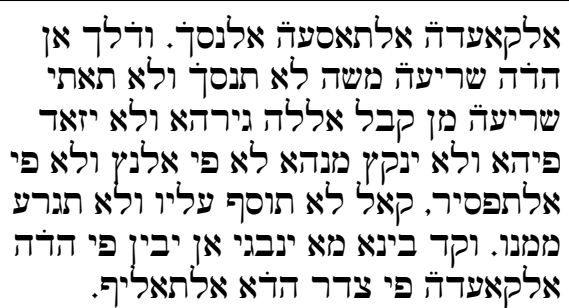 \\
\hline
\end{tabular}

63 Sayılar 21.18

64 Tekvin 10.6

65 Tekvin 36.39

66 Çıkış 20.2

67 Tesniye 6.4

68 Sayılar 15.31

69 Eyüp 11.9 
Dokuzuncu kaide: Nesh’tir. Yani Musa şeriatı neshedilmeyecektir ve Allah tarafından da başka şeriat gelmeyecektir. Ne tefsirinde ne de ayetinde onda bir artma ve eksilme olmayacaktır. (Yaratıcı) buyurmuştur ki "Ona bir şey eklemeyecek ve çıkarmayacaksınız"70. Bu kaide ile ilgili söylenmesi gerekenleri bu eserin başında açıkladık.

\begin{tabular}{|c|c|}
\hline 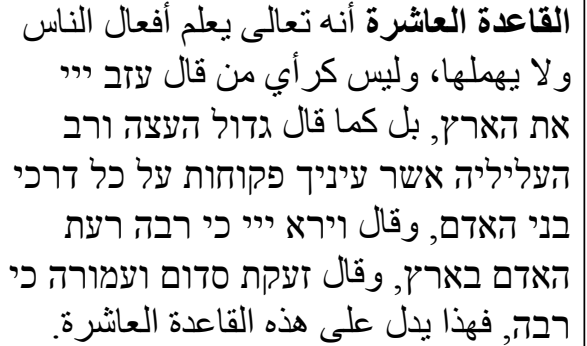 & 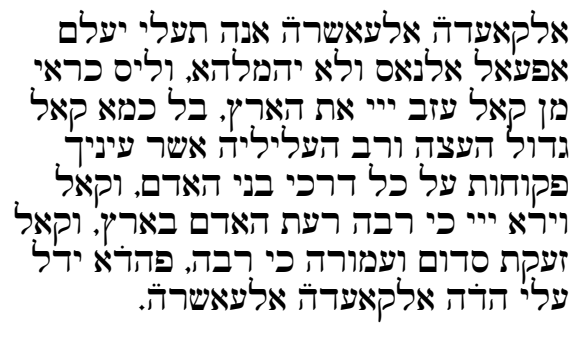 \\
\hline
\end{tabular}

Onuncu kaide: Yaratıcı insanların fiillerini bilir ve onları ihmal etmez. $\mathrm{Bu}$ "Rab ülkeyi bıraktı"" diyenin görüşü gibi değildir. Bilakis "Öğütlerin ne büyük, işlerin ne güçlü! Gözlerin insanların bütün yaptıklarına açıktır"72 ifadesindeki gibidir. Rab yine şöyle dedi "Rab bakt1, yeryüzünde insanın yaptığı kötülük çok"73. Yine şöyle buyurdu "“'Sodom'la Gomora büyük suçlama altında, günahları çok ağır"74. Bunlar onuncu kaideye işaret ederler.

\begin{tabular}{|c|c|}
\hline 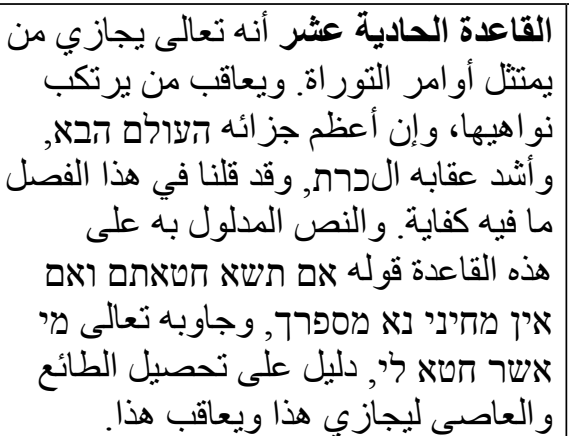 & 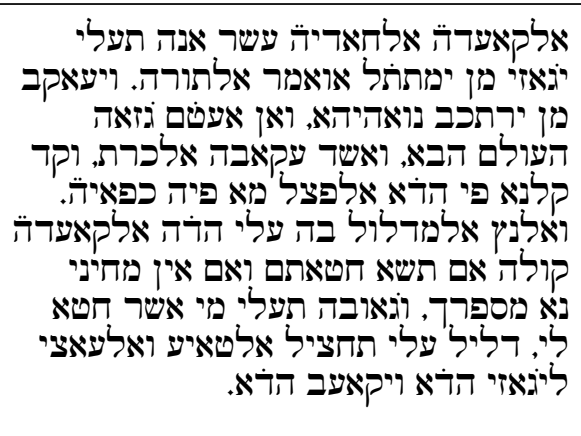 \\
\hline
\end{tabular}

On birinci kaide: Yaratıcı Tevrat'ın emirlerini yerine getirenleri ödüllendirecek, yasaklarını yapanlarını cezalandıracaktır. (Emri yerine getirenin) en

70 Tesniye 4.2

71 Hezekiel 8.12, 9.9

72 Yeremya 32.19

73 Tekvin 6.5

74 Tekvin 18.20 
büyük ödülü öteki dünya olacaktır. (Yasakları yapanın) en şiddetli cezası ise yok olmaktır. ${ }^{75} \mathrm{Bu}$ bölümde yeterince bu konuyu açıkladık. "Lütfen günahlarını bağışla, yoksa yazdığın kitaptan adımı sil. Rab, 'Kim bana karşı günah işlediyse onun adını sileceğim' diye karşılık verdi" "76 ayeti bu kaideye işaret eder. Bu ifadeler itaat edenin ödüllendirileceğine, isyan edenin de cezalandırılacağına delil teşkil eder.

\begin{tabular}{|c|c|}
\hline 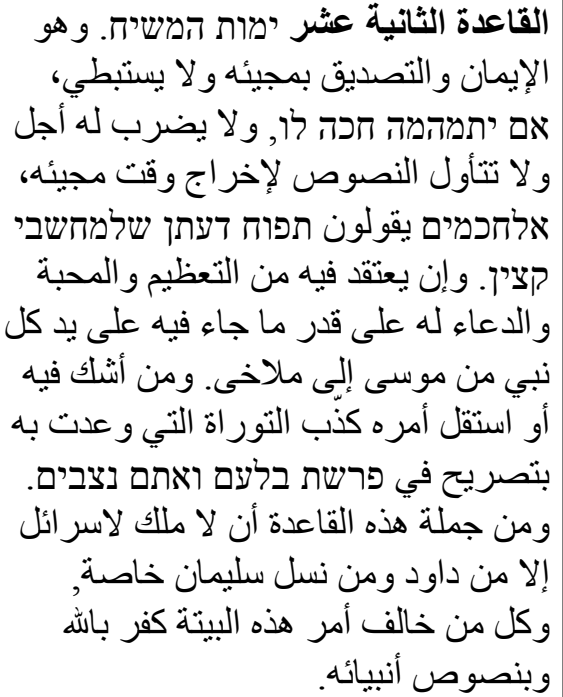 & 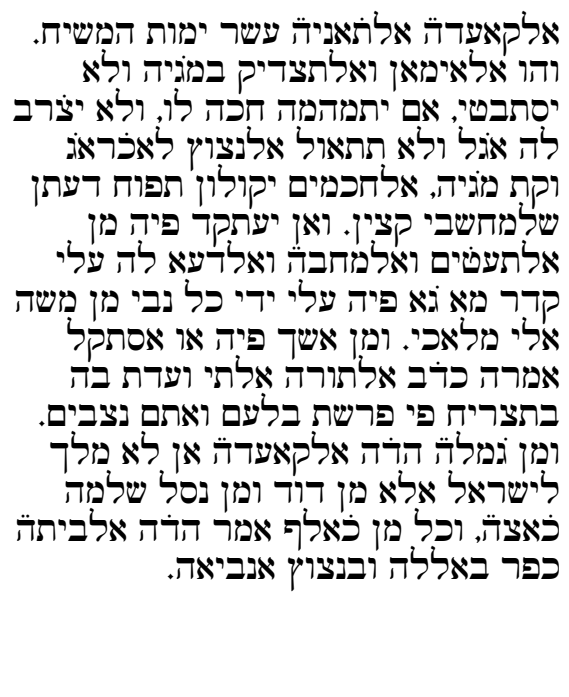 \\
\hline
\end{tabular}

On ikinci kaide: Mesih'in gelişi hakkındadır. Geleceğine iman etmek ve tasdik etmektir. "Gecikiyormuş gibi görünse de bekle olacakları" de denildiği gibi gelmesi uzun sürmeyecek. Gelişi ile ilgili bir zaman takdir edilemez ve ayetlerden vakit de çıkarılamaz. Din bilginleri "alemin sonu ile ilgili hesap yapanların bilgileri artsın"78 demişlerdir. (Mümin) Musa'dan Malaki'ye kadar her peygamber ile bildirildiği ölçüde muhabbet ve ta'zim ile ona inanır ve gelmesi için dua eder. Her kim ki (Mesih'in geleceğinden) şüphe duyar veya bu işi hafife alırsa Tevrat'ı yalanlamış olur ki Tevrat (bunu) özel-

75 Karet kelimesi ile ifade edilen ve en ağır cezalardan biri kabul edilen bu ceza, yok olma, kökünü kazıma anlamına gelir. İlahi bir takdir olarak uzun yaşayamayacakları ve ahiretten nasipleri olmadığı şeklinde açıklanır. Mişna Keritot 1.1'de cezası karet olan otuz altı çeşit günahın listesi verilmektedir.

76 Çıkış 32.32-33

77 Habakkuk 2.3

78 TB, Sanhedrin 99a-b 


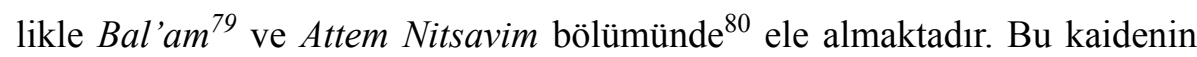
bir parçası olarak İsrail'de kral yalnızca Davut ve Süleyman'ın neslindendir. Her kim bu sülalenin emirlerine muhalefet ederse Allah'1 ve peygamberlerin ayetlerini inkar etmiş olur.

\begin{tabular}{|c|c|}
\hline بيناها. القاعدة الثالثة عشر תחיית המתים. وقد & אמקתים. וקדה בלינאלה \\
\hline
\end{tabular}

On üçüncü kaide: Ölülerin diriltilmesidir. Onu (daha önce) açıklamıştık. 